\title{
C-reactive protein and cardiovascular disease: From animal studies to the clinic (Review)
}

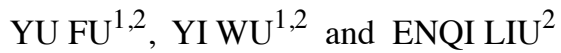 \\ ${ }^{1}$ MOE Key Laboratory of Cell Activities and Stress Adaptations, School of Life Sciences, \\ Lanzhou University, Lanzhou, Gansu 730000; ${ }^{2}$ Research Institute of Atherosclerotic Disease, \\ Xi'an Jiaotong University Health Science Center, Xi'an, Shaanxi 710061, P.R. China
}

Received September 16, 2019; Accepted May 5, 2020

DOI: $10.3892 /$ etm.2020.8840

\begin{abstract}
C-reactive protein (CRP) and cardiovascular disease (CVD) have long been important research topics. $\mathrm{CRP}$ is an acute phase protein, while CVD is an inflammatory condition. The association between CRP and CVD remains controversial and has been attracting increasing attention. Traditionally, the main marker of CVD is considered to be low-density lipoprotein cholesterol. However, due to its unique characteristics, CRP may represent a novel marker or a new therapeutic target for CVD. Clinical studies have demonstrated that CRP is a predictor of CVD, but whether it is directly involved in the development and progression of CVD has yet to be fully elucidated. Recent clinical studies have demonstrated that lowering plasma CRP levels may reduce the incidence of CVD. The aim of the present review was to investigate the association between CRP and CVD, particularly atherosclerosis, from laboratory animal studies to clinical research.
\end{abstract}

\section{Contents}

1. Introduction

2. CRP

3. CVD

4. Animal studies

5. Clinical studies

6. Possible mechanism of CRP in atherosclerosis

7. Discussion

8. Conclusion

Correspondence to: Professor Enqi Liu, Research Institute of Atherosclerotic Disease, Xi'an Jiaotong University Health Science Center, 76 West Road of Yanta, Xi'an, Shaanxi 710061, P.R. China E-mail: liuenqi@mail.xjtu.edu.cn

Key words: C-reactive protein, cardiovascular disease, atherosclerosis, animal studies, clinical studies

\section{Introduction}

Cardiovascular disease (CVD) is the leading cause of death worldwide (1). According to the Global Burden of Disease Study, the number of deaths from CVD reached 17.9 million in 2015 , which was markedly higher compared with the 12.3 million deaths from CVD reported in $1990(2,3)$. Due to its high mortality and morbidity rates, it is crucial to predict the risk of CVD. Atherosclerosis is the pathological basis of several CVDs, including coronary heart disease, peripheral vascular disease and cerebral infarction. Atherosclerosis is a chronic inflammatory disease, chiefly manifested by activation of endothelial cells, adhesion and migration of monocytes, accumulation of foam cells, formation of atherosclerotic plaques, plaque rupture and thrombosis (4). C-reactive protein (CRP) is an acute phase reactive protein. The association between CRP as an acute phase response protein and CVD has been controversial. The aim of the present review was to investigate whether CRP is merely a biomarker of inflammatory diseases, or if it is causally associated with CVD and, thus, directly involved in the pathogenesis of CVD.

\section{CRP}

Tillett and Francis (5) first observed in 1930 that a protein in the serum of patients with acute inflammation reacted with the ' $\mathrm{C}$ ' carbohydrate antibody of pneumococcus, giving rise to the name 'CRP'. CRP is mainly produced by the liver (6), has a ring-shaped pentamer symmetrical structure and the protoplasts are joined by non-covalent bonds (7). CRP is a highly sensitive marker of inflammation and tissue damage, and it is considered an acute phase protein (8). When inflammation occurs in the body, the CRP levels increase with the inflammatory response. In healthy adult volunteers, the median CRP concentration is $0.8 \mathrm{mg} / \mathrm{l}$, with $90 \%$ of the cases at $<3 \mathrm{mg} / \mathrm{l}$ and $99 \%$ at $<10 \mathrm{mg} / \mathrm{l}$ (9). However, following acute phase stimulation, the CRP levels may increase 100- or even 500-fold (10). When CRP aggregates or binds to macromolecule ligands, the classical pathway of complement activation can be achieved through interactions with Clq $(11,12)$. CRP levels are routinely assessed in the clinic. In clinical studies, the 'high-sensitivity' CRP (hs-CRP) detection method has come to be considered as 
a more sensitive method for detecting atherosclerotic inflammation. The reason for this is that in order to detect CRP with high sensitivity, the detection limit needs to be minimized as far as possible (13-15). The US Centers for Disease Control and Prevention has previously issued a statement that classifies hs-CRP levels and risk categories as follows: low risk $<1.0 \mathrm{mg} / \mathrm{l}$; intermediate risk $1.0-3.0 \mathrm{mg} / \mathrm{l}$; and high risk $>3.0 \mathrm{mg} / \mathrm{l}(16,17)$.

\section{CVD}

CVD is a term used to collectively describe diseases involving the heart and/or vasculature. CVD mainly includes diseases caused by atherosclerosis (1). The Emerging Risk Factors Collaboration is based on a large number of population studies and has found that CRP concentrations are closely associated with coronary arterial disease, cancer, ischemic stroke and vascular diseases (18). However, more noteworthy is the comparison between men and women, as men develop CVD earlier and the risk of CVD increases with age (19). Atherosclerosis is a chronic inflammatory disease that is initially asymptomatic. Early atherosclerosis is associated with limited plaque formation, which does not affect the blood circulation (20). However, the plaques forming on the inner arterial wall gradually increase in size, causing narrowing of the arterial lumen and/or thrombus formation. At this stage, the blood supply to each organ may become compromised, causing manifestations of CVD $(4,20)$. Atherosclerosis is the main cause of the high mortality rates of CVD (21). When CVD occurs in the body, the CRP levels increase; therefore, it may be inferred that there is an association between CRP and CVD (22-29). Based on a large number of animal experiments and clinical studies, CRP is a pathogenic factor that warrants further investigation (27,30-34). The association between CVD and CRP, and whether CRP can be used as a novel marker or target for the treatment of CVD, must be further verified in animal experiments and clinical studies.

\section{Animal studies}

Mice, rats and rabbits are frequently used to construct animal models in several preclinical studies investigating CVD (35), whereas the majority of the animal models that study CRP use mice and rabbits (36). To reveal the phylogenetic relationships of CRP, the CRP protein sequence of 14 most frequently used animal models in CVD research, including human (NP_000558.2), chimpanzee (XP_001170732.2), Rhesus monkey (XP_001117250.2), crab-eating macaque (NP_001306322.1), rabbit (NP_001075734.1), guinea pig (XP_003466601.1), naked mole-rat (XP_004858808.1), rat (NP_058792.1), golden hamster (XP_005078251.1), mouse (NP_031794.3), cattle (NP_001137569.1), sheep (XP_027821246.1), dog (NP_001301045.1), horse (XP_023496680.1) were downloaded from the NCBI protein database (https://www.ncbi.nlm.nih.gov/protein/). Subsequently, the phylogenetic tree of maximum likelihood was constructed using MEGA7 (37) (Fig. 1). Except for non-human primates, it may be inferred that rabbits and humans were placed in the same cluster. Rats and mice were in relatively far clusters, suggesting the genetic priority of rabbits and non-human primates as animal models in studies of CRP-related CVD.

There is controversy regarding the association between CRP and CVD in animal experiments. Several studies have demonstrated that CRP can promote the pathological process of atherosclerosis $(30,31,38)$. Using a rat carotid angioplasty model, an experiment revealed that CRP can promote the migration and proliferation of vascular smooth muscle cells, an increase in the collagen content and the production of neointima (38). Paul et al (30) also suggested that human CRP over expression accelerates the progression of atherosclerosis in apolipoprotein $\mathrm{E}$ knockout $\left(\mathrm{ApoE}^{-/}\right)$mice and that CRP in lesions is associated with increased C3, angiotensin type 1 receptor (AT1-R), vascular cell adhesion molecule 1 and collagen content. However, a previous study by Hirschfield et al (39) demonstrated that after 56 weeks of observation, male $\mathrm{ApoE}^{-/-}$mice expressing human CRP did not display promotion of the development of atherosclerosis, but human CRP and mouse complement deposition were found in the plaques. Of note, it has been previously suggested that human CRP does not promote atherosclerosis, but rather may reduce the development of atherosclerosis (40). By contrast, Teupser et al (41) suggested that the absence of CRP in mice exacerbates atherosclerotic lesions.

Our group at the Research Institute of Atherosclerotic Disease has also performed animal studies to explore the role of CRP in CVD $(31,42)$. High-cholesterol feed was used to induce atherosclerosis in rabbits and the association between CRP and atherosclerosis was investigated. The results demonstrated that the CRP content was positively correlated with the size of the atherosclerotic lesions (31). When an acute embolic stroke occurs in rabbits, the level of CRP in the plasma increases with increasing infarct size, and the CRP level in the plasma is closely associated with the area occupied by the infarcted lesion (42). In addition, we also found that decreased plasma CRP levels did not affect the development of atherosclerosis (43). These results indicate the presence of a close association between CRP and CVD.

However, several studies have failed to demonstrate a correlation between CRP and atherosclerosis, and it has been reported that CRP does not affect the development of atherosclerosis (43-48). Tennent et al (44) and Reifenberg et al (45) found no significant difference in the formation of atherosclerotic lesions in $\mathrm{ApoE}^{-/-}$mice between transgenic human and rabbit CRP. It has also been reported that CRP does not play a role even in early atherosclerosis $(46,47)$. However, initial studies have revealed that mouse models for studying CRP may carry certain disadvantages, as the CRP levels in the plasma of mice stimulated by inflammation were markedly low compared with those in humans and rabbits (49). Compared with mice, the lipoprotein metabolism of rabbits and the response of CRP, an acute phase reactant, were more similar to that in humans $(50,51)$.

In subsequent animal experiments, researchers have generally turned to the study of transgenic rabbits. Koike et al (48) observed that CRP did not affect the formation of aortic or coronary atherosclerotic lesions in transgenic rabbits. This suggests that, even at higher levels, CRP does not affect the occurrence and development of atherosclerosis. We found that, although antisense oligonucleotides to CRP were used 


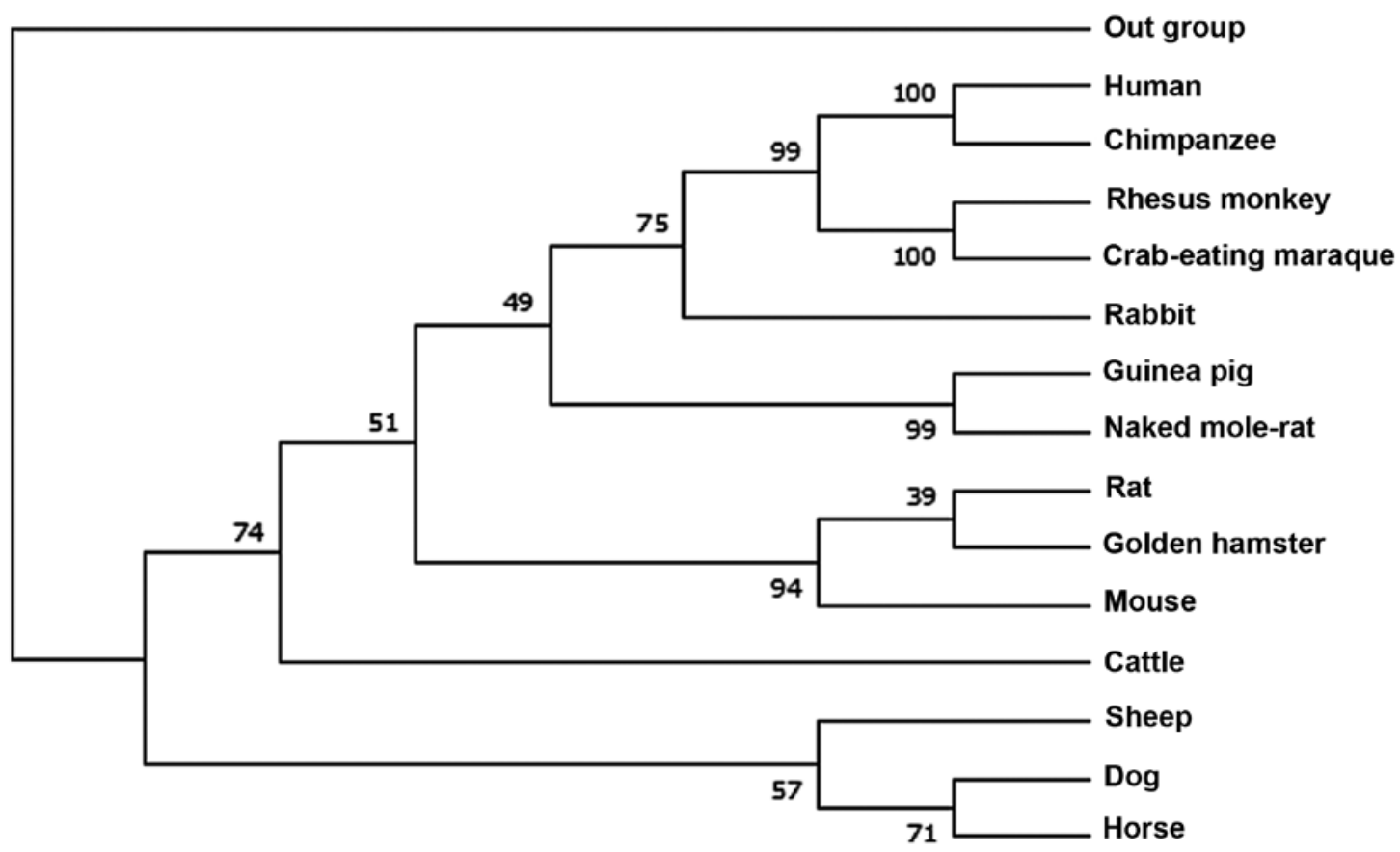

Figure 1. Molecular phylogenetic analysis animal models commonly used in CRP and CVD studies.

to reduce the plasma level of CRP, the progression of atherosclerosis in the aorta and coronary artery of rabbits was not affected (43). Therefore, in laboratory animals (mice, rats and rabbits) studies, it has not been confirmed that an increase or decrease in CRP levels affects the progression of atherosclerotic lesions. The major animal studies between CRP and CVD are summarized in Table I. However, concerning the currently available experimental studies, the results of mouse experiments have been contradictory. Most researchers have not demonstrated that CRP affects CVD lesions (39,41,44-47). Therefore, the results of animal experiments have failed to determine whether there is a correlation or a causal association between CRP and CVD, and further studies are required.

\section{Clinical studies}

A large volume of clinical data indicates that the detection of hs-CRP is of predictive value in CVD (22-26) and is also a risk factor and biomarker for CVD (27-29,52). Studies have demonstrated that the detection of CRP levels may help identify early complications in patients with acute myocardial infarction and acute coronary artery disease $(33,34)$. Similarly, Hutchinson et al (53) found in early large-scale clinical studies that age increases are directly proportional to CRP levels, suggesting that CRP may be closely associated with an increased risk of CVD. Ridker et al (27) monitored the CRP levels of 27,939 patients for up to 8 years and suggested that the probability of CVD increased with increasing CRP levels. In subsequent study, a follow-up analysis of $>6,000$ patients revealed an increased risk of acute cardiovascular events in patients with higher CRP levels (54). These larger population studies have suggested that CRP may be a predictor of CVD.

For patients with stable or unstable angina, detecting serum CRP levels may also predict coronary events (55), and real-time detection of CRP plasma levels in patients with unstable angina after discharge can effectively predict the risk of recurrent coronary events (56). Therefore, CRP can predict the severity of CVD and the detection of the CRP levels may effectively prevent CVD $(27,57,58)$. However, whether CRP is merely a predictive biomarker of inflammation in CVD, or whether reducing the level of CRP is beneficial in the treatment of CVD, have yet to be clearly determined. Previous studies have demonstrated that long-term use of statins can indeed reduce serum CRP levels in patients with acute myocardial infarction, which may prove beneficial in the treatment of acute myocardial infarction $(52,59)$. In the well-known Justification for use of statins in prevention: An intervention trial evaluating Rosuvastatin (JUPITER) trial, the use of statins significantly reduced the level of CRP in patients by $37 \%$, while the level of cholesterol was also significantly reduced, leading to a lower incidence of CVD (60). This result has also been reported in other clinical studies (59,61-64).

However, the JUPITER study did not clearly demonstrate whether the cause of CVD protection was a decrease in cholesterol or a consequence of a decrease in CRP levels. A previous study reported that CRP appeared to predict CVD better than low-density lipoprotein cholesterol levels (27). Earlier studies have also reported that CRP and interleukin-6 are strongly associated with an increased risk of CVD $(22,25)$. This hypothesis was further confirmed by Ridker et al (65) in the recent Canakinumab antiinflammatory thrombosis outcome study (CANTOS) trial study, where patients with a history of myocardial infarction were treated with canakinumab, an anti-inflammatory human monoclonal antibody targeting interleukin-1 $\beta$. Canakinumab treatment significantly reduced the level of CRP in plasma without lowering lipid levels in vivo, thereby reducing the incidence of recurrent CVD. This is a significant finding, showing a potential new method for the treatment of atherosclerotic diseases in the future. There 
Table I. The main animal experiments to explore the relationship between CRP and atherosclerosis.

\begin{tabular}{|c|c|c|c|c|c|c|}
\hline Authors, year & Genotype & Sex & Diet & $\mathrm{CRP}, \mu \mathrm{g} / \mathrm{ml}$ & Significance & Refs. \\
\hline Paul et al, 2004 & huCRPtg ${ }^{+} / \mathrm{ApoE}^{-/-}$ & $\mathrm{M}+\mathrm{F}$ & SD & $\begin{array}{l}M:>100^{\mathrm{a}} \\
\mathrm{F}: 70^{\mathrm{a}}\end{array}$ & $\begin{array}{l}\mathrm{P}<0.02(\mathrm{M}) \\
\text { proatherogenic }\end{array}$ & (30) \\
\hline Reifenberg et al, 2005 & $\mathrm{rbCRPtg}^{+} / \mathrm{ApoE}^{-/-}$ & $\mathrm{M}+\mathrm{F}$ & Protein-rich diet & $\begin{array}{l}\text { M: } 29.3 \pm 18.2^{\mathrm{b}} \\
\text { F: } 29.0 \pm 25.1^{\mathrm{b}}\end{array}$ & ns & $(45)$ \\
\hline Trion et al, 2005 & huCRPtg $^{+} / \mathrm{E} 3 \mathrm{~L}$ & $\mathrm{M}+\mathrm{F}$ & Hypercholesterolemic diet & $\begin{array}{l}M: 10.2 \pm 6.5^{\mathrm{b}} \\
F: 0.2 \pm 0.1^{\mathrm{b}}\end{array}$ & ns & $(47)$ \\
\hline Hirschfield et al, 2005 & huCRPtg ${ }^{+} / \mathrm{ApoE}^{-/-}$ & M & SD & $<30^{\mathrm{a}}$ & ns & (39) \\
\hline Tennent et al, 2008 & huCRPtg ${ }^{+} / \mathrm{ApoE}^{-/-}$ & $\mathrm{M}$ & SD & $1.76-31.79^{\mathrm{a}}$ & ns & $(44)$ \\
\hline Kovacs et al, 2007 & $\mathrm{huCRPtg}^{+} / \mathrm{LDLR}^{-/-}$ & M & SD & $24.0-51.8^{\mathrm{a}}$ & $\begin{array}{l}\mathrm{P}<0.05 \\
\text { antiatherogenic }\end{array}$ & $(40)$ \\
\hline Torzewski et al, 2008 & $\mathrm{huCRPtg}^{+} / \mathrm{LDLR}^{-/-}$ & M & WTD & $7.4 \pm 4.4-12.8 \pm 4.8^{\mathrm{b}}$ & ns & $(46)$ \\
\hline Teupser et al, 2011 & $\begin{array}{l}\mathrm{CRP}^{-/ /} / \mathrm{ApoE}^{-/-}, \\
\mathrm{CRP}^{-/ /} / \mathrm{LDLR}^{-/}\end{array}$ & $\mathrm{M}+\mathrm{F}$ & Low fat, semisynthetic diet & $7.5^{\mathrm{a}}$ & ns & $(41)$ \\
\hline Koike et al, 2009 & huCRPtg ${ }^{+}$rabbits & $\mathrm{M}$ & Cholesterol-rich diet & $57.8 \pm 20.6^{\mathrm{b}}$ & ns & $(48)$ \\
\hline Yu Q et al, 2014 & WHHL rabbits & M & SD & $<30^{\mathrm{a}}$ & ns & $(43)$ \\
\hline
\end{tabular}

CRP, C-reaction protein; hu, human; rb, rabbit; WHHL rabbits, Watanabe heritable hyperlipidemic rabbits; M, male; F, female; SD, standard

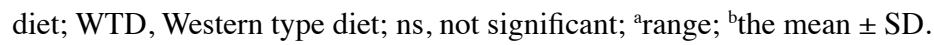

is a close association between CRP and CVD: The detection of CRP levels may better predict the incidence of CVD and a decrease in CRP levels may lead to a reduced risk of CVD. A summary of the results of previous major clinical studies is shown in Table II.

\section{Possible mechanism of CRP in atherosclerosis}

As Ridker et al (65) suggested, a number of publications have also indicated that CRP may not be simply a predictor, but that it may also be directly involved in the pathogenesis of CVD and play a role in promoting the development of atherosclerotic lesions (66-68). Pasceri et al (69) were the first to demonstrate that increased CRP levels can induce the production of monocyte chemotactic protein 1 . Moreover, previous studies have shown the expression of adhesion molecules in human endothelial cells (70-72). It has also been demonstrated that when injecting human CRP into mice and rats, the increase in CRP in the body affected endothelial nitric oxide synthase activity and led to endothelial cell dysfunction (73-76). CRP may also reduce the expression of endothelial nitric oxide synthase in endothelial cells $(77,78)$, and significantly increase the expression levels of vascular cell adhesion molecule, intracellular adhesion molecule and monocyte chemokine (79), thus inhibiting angiogenesis (80). Teoh et al (81) confirmed this finding in mice over-expressing CRP transgenes, further suggesting that CRP can cause endothelial cell dysfunction. In clinical studies, CRP levels have also been associated with impaired endothelial vascular activity (82-84). Although there is a clear correlation between CRP and endothelial cells, it is not clear whether CRP affects the development and progression of atherosclerosis. Other studies have also demonstrated that CRP may play a direct role in the pathogenesis of atherosclerosis by activating endothelial cells $(69,72,77,79,80)$.
Subsequently, Devaraj et al (85) found through studying human aortic endothelial cells, that CRP can participate in the process of atherosclerosis by upregulating nuclear factor (NF) $-\kappa \mathrm{B}$, inducing the synthesis of interleukin-8. Endothelial cells are markers of early atherosclerosis and the occurrence of atherosclerotic diseases is closely associated with endothelial cells, monocytes/macrophages and vascular smooth muscle cells (86). Thus, studies on those types of cells may support the role of CRP in atherosclerosis. However, there is controversy regarding the source of CRP, as it may be argued that activating endothelial cells produces CRP, while human coronary artery smooth muscle cells can also synthesize CRP following stimulation by inflammatory cytokines (87). In atherosclerotic diseases, the migration and proliferation of smooth muscle cells is an important pathological event (88). CRP can upregulate the expression of AT1-R in vascular smooth muscle and further promote the migration and proliferation of vascular smooth muscle cells (38). Subsequent study have demonstrated that CRP can activate the function of Fc $\gamma$ RIIa and NADPH oxidase 4 through a pro-inflammatory mechanism, thereby inducing vascular smooth muscle cells to produce reactive oxygen species (89). However, Liu et al $(90,91)$ found that CRP can activate the $\mathrm{NF}-\kappa \mathrm{B}$ signaling pathway through toll-like receptor 4 and promote the expression of inflammatory cytokines in rat vascular smooth muscle cells. Other researchers suggested that CRP can induce monocytes to express tissue factor and stimulate the release of matrix in monocytes/macrophages, further promoting the rupture of atherosclerotic plaques and, eventually, leading to the occurrence of CVD (92-94). Ballou and Lozanski (95) demonstrated that CRP can induce the release of inflammatory cytokines from human monocytes. Torzewski et al (96) considered that CRP deposition in early atherosclerotic lesions may occur earlier than monocyte 
Table II. Main clinical studies exploring the relationship between CRP and atherosclerosis.

\begin{tabular}{|c|c|c|c|c|c|c|}
\hline Authors, year & Medical history & Sex & $\begin{array}{l}\text { Number of } \\
\text { participants }\end{array}$ & $\mathrm{CRP}, \mu \mathrm{g} / \mathrm{ml}$ & $\begin{array}{l}\text { Correlation between } \\
\text { CRP and CVD }\end{array}$ & Refs. \\
\hline Ridker et al, 1997 & Healthy population & M & 543 & $1.51-1.13^{\mathrm{a}}$ & Prediction & (22) \\
\hline Haverkate F et al, 1997 & Outpatients with angina & $M+F$ & 2,121 & $>3.6^{\mathrm{a}}$ & Prediction & (55) \\
\hline Ridker PM et al, 1999 & $\begin{array}{l}\text { Cholesterol and recurrent events; } \\
\text { randomly selected participants }\end{array}$ & $M+F$ & 472 & $<4.5^{\mathrm{a}}$ & $\begin{array}{l}\text { Positive } \\
\text { CRP } \downarrow \text { CVD } \downarrow\end{array}$ & $(52)$ \\
\hline Koenig, W et al, 1999 & General population & M & 936 & $0.05-90.8^{\mathrm{a}}$ & Prediction & (23) \\
\hline Danesh, J et al, 2000 & General population & M & 1,531 & $>2.4^{\mathrm{a}}$ & Prediction & (24) \\
\hline Ridker PM et al, 2002 & Healthy population & $\mathrm{F}$ & 27,939 & $1.4-2.3^{\mathrm{a}}$ & Prediction & (27) \\
\hline Danesh J et al, 2004 & Cardiovascular disease population & $M+F$ & 18,569 & $1.75 \pm 5.3^{\mathrm{b}}$ & Prediction & (54) \\
\hline Ridker et al, 2008 & $\begin{array}{l}\text { Healthy population } \\
\text { (hyperlipidemia, hs-CRP level) }\end{array}$ & $M+F$ & 17,802 & $\sim 4.2^{\mathrm{a}}$ & $\begin{array}{l}\text { Positive } \\
\mathrm{CRP} \downarrow \mathrm{CVD} \downarrow \mathrm{LDL} \downarrow\end{array}$ & (60) \\
\hline Ridker PM et al, 2017 & $\begin{array}{l}\text { Previous myocardial infarction, } \\
\text { hs-CRP level }\end{array}$ & $\mathrm{F}$ & 10,061 & $\sim 4.2^{\mathrm{a}}$ & $\begin{array}{l}\text { Positive } \\
\text { CRP } \downarrow \text { CVD } \downarrow\end{array}$ & (65) \\
\hline
\end{tabular}

M, male; F, female; CRP, C-reaction protein; CVD, cardiovascular diseases; LDL, low density lipoprotein cholesterol; $\downarrow$, reduction; ${ }^{a}$ range; b the mean \pm SD.

infiltration, which is a characteristic of early atherosclerotic lesions, indicating that CRP may play a key role in the production of monocytes.

The presence of CRP in human atherosclerotic plaques has been confirmed $(32,87,97-99)$, and complement activation has been detected in atherosclerotic plaques (100-102). Torzewski et al (103) demonstrated the presence of complement proteins in plaques by studying early atherosclerotic lesions in humans and animals. Whether the CRP detected in atherosclerotic plaques indicates that CRP is implicated in the development of atherosclerosis and promotes plaque formation by activating the complement system requires further confirmation in future studies.

\section{Discussion}

As for the association between CRP and CVD, CRP has been confirmed as a predictor of CVD. However, the causal relationship between CRP and CVD has yet to be confirmed. The results of animal and clinical studies to date have been contentious. Due to the differences between animals and humans, the results of animal models require further research. CRP has long been used in clinical research as an acute phase protein, and CRP detection shows predictive value in CVD research $(27,57)$. Several researchers have classified CRP as a clinical predictor of CVD $(56,104-106)$. However, CRP has been found to be associated with the function of endothelial cells, monocytes/macrophages and smooth muscle cells, and it has also been detected in atherosclerotic plaques $(38,81,85,90,92,97)$. Previous studies have demonstrated that CRP is produced by the liver and it is released in the blood and delivered to the corresponding tissue when there are inflammatory symptoms (107-110). However, whether there is another source of CRP remains unknown. If CRP can promote the migration and proliferation of endothelial cells, monocytes/macrophages and vascular smooth muscle cells, and then activate the complement system and participate in the occurrence of CVD, the association between CRP and CVD would constitute a major discovery. However, most researchers believe that the involvement of CRP in the pathogenesis of atherosclerosis by activating endothelial cells requires further confirmation. Based on the current experimental results, the causal association between CRP and CVD is uncertain. Research has long been performed using mouse models, but these models carry certain disadvantages when studying the association between CRP and CVD $(45,111,112)$. In order to better simulate the human inflammatory response, better animal models must be designed, to simulate the overall or local mechanisms of action of CRP. Currently, the role of CRP in inflammation depends on synthetic sources (113), which may be the key to the current controversy between CRP and CVD. The results of this study show that CRP secreted by the liver is difficult to enter extrahepatic tissues, so CRP may be produced by extrahepatic tissues and transported back to the blood (113).

However, other animal models are required for future studies, including rabbits and non-human primates. Animal model studies using different species are valuable. However, these animal models are all systemic studies, so it is unknown whether the local effects caused by the expression or deletion of genes in animal models can more closely simulate human disease. There is evidence that the level of circulating CRP mainly reflects the underlying inflammatory state, the expression of local CRP is closely associated with the development of the disease, and with locally increased CRP at different sites potentially causing inflammation (114). Therefore, studying the local effects of CRP may be a better model of human disease. The clinical CANTOS experiment was the first to demonstrate that CVD can be effectively treated by anti-inflammatory drugs and that by reducing the level of CRP, it may be possible to reduce the risk of CVD (65). However, there is a limitation in that the risk of CVD is reduced following anti-inflammatory 
therapy, but this inflammatory suppression may affect the treatment of other diseases. This requires more thorough research in the clinical setting.

\section{Conclusion}

In animal and clinical studies, CRP plays an important role in CVD. Although the CANTOS study shows that drugs can reduce CRP levels and the risk of CVD (65), its cardiovascular effects have not been clearly determined. A large number of animal studies and clinical conclusions have confirmed CRP as a biomarker, but whether CRP suppression exerts cardiovascular protective effects and whether it affects the occurrence and development of other diseases requires further comprehensive assessment.

\section{Acknowledgements}

Not applicable.

\section{Funding}

No funding was received.

\section{Availability of data and materials}

The datasets generated and/or analyzed during the current study are available in the NCBI protein database, [https://www. ncbi.nlm.nih.gov/protein/.human (NP_000558.2), chimpanzee (XP_001170732.2), Rhesus monkey (XP_001117250.2), crab-eating macaque (NP_001306322.1), rabbit (NP_001075734.1), guinea pig (XP_003466601.1), naked mole-rat (XP_004858808.1), rat (NP_058792.1), golden hamster (XP_005078251.1), mouse (NP_031794.3), cattle (NP_001137569.1), sheep (XP_027821246.1), dog (NP_001301045.1), horse (XP_023496680.1)].

\section{Authors' contributions}

YF wrote the manuscript. YW and EL reviewed and revised the manuscript. All authors read and approved the final manuscript.

\section{Ethics approval and consent to participate}

Not applicable.

\section{Patient consent for publication}

Not applicable.

\section{Competing interests}

The authors declare that they have no competing interests.

\section{References}

1. Thomas H, Diamond J, Vieco A, Chaudhuri S, Shinnar E, Cromer S, Perel P, Mensah GA, Narula J, Johnson CO, et al: Global Atlas of Cardiovascular Disease 2000-2016: The Path to Prevention and Control. Glob Heart 13: 143-163, 2018.
2. Mortality GBD: Global, regional, and national age - sex specific all-cause and cause-specific mortality for 240 causes of death, 1990-2013: A systematic analysis for the Global Burden of Disease Study 2013. Lancet 385: 117-171, 2015.

3. GBD 2015 Mortality and Causes of Death Collaborators: Global, regional, and national life expectancy, all-cause mortality, and cause-specific mortality for 249 causes of death, 1980-2015: A systematic analysis for the Global Burden of Disease Study 2015. Lancet 388: 1459-1544, 2016.

4. Ross R: Atherosclerosis - an inflammatory disease. N Engl J Med 340: 115-126, 1999.

5. Tillett WS and Francis T Jr: Serological reactions in pneumonia with a non-protein somatic fraction of pneumococcus. J Exp Med 52: 561-571, 1930.

6. Taylor $\mathrm{AW}, \mathrm{Ku} \mathrm{NO}$ and Mortensen RF: Regulation of cytokine-induced human $\mathrm{C}$-reactive protein production by transforming growth factor-beta. J Immunol 145: 2507-2513, 1990.

7. Thompson D, Pepys MB and Wood SP: The physiological structure of human C-reactive protein and its complex with phosphocholine. Structure 7: 169-177, 1999.

8. Pepys MB and Baltz ML: Acute phase proteins with special reference to $\mathrm{C}$-reactive protein and related proteins (pentaxins) and serum amyloid A protein. Adv Immunol 34: 141-212, 1983.

9. Shine B, de Beer FC and Pepys MB: Solid phase radioimmunoassays for human C-reactive protein. Clin Chim Acta 117: 13-23, 1981.

10. Pepys MB and Hirschfield GM: C-reactive protein: A critical update. J Clin Invest 111: 1805-1812, 2003.

11. Volanakis JE and Kaplan MH: Interaction of C-reactive protein complexes with the complement system. II. Consumption of guinea pig complement by CRP complexes: Requirement for human Clq. J Immunol 113: 9-17, 1974.

12. Claus DR, Siegel J, Petras K, Osmand AP and Gewurz H: Interactions of $\mathrm{C}$-reactive protein with the first component of human complement. J Immunol 119: 187-192, 1977.

13. Moutachakkir M, Lamrani Hanchi A, Baraou A, Boukhira A and Chellak S: Immunoanalytical characteristics of C-reactive protein and high sensitivity C-reactive protein. Ann Biol Clin (Paris) 75: 225-229, 2017.

14. Calabrò P, Golia E and Yeh ET: CRP and the risk of atherosclerotic events. Semin Immunopathol 31: 79-94, 2009.

15. Koenig W: High-sensitivity C-reactive protein and atherosclerotic disease: From improved risk prediction to risk-guided therapy. Int J Cardiol 168: 5126-5134, 2013.

16. Pearson TA, Mensah GA, Alexander RW, Anderson JL, Cannon RO III, Criqui M, Fadl YY, Fortmann SP, Hong Y, Myers GL, et al; Centers for Disease Control and Prevention; American Heart Association: Markers of inflammation and cardiovascular disease: application to clinical and public health practice: A statement for healthcare professionals from the Centers for Disease Control and Prevention and the American Heart Association. Circulation 107: 499-511, 2003.

17. Ridker PM: Clinical application of C-reactive protein for cardiovascular disease detection and prevention. Circulation 107: 363-369, 2003.

18. Kaptoge S, Di Angelantonio E, Lowe G, Pepys MB, Thompson SG, Collins R and Danesh J: Emerging Risk Factors Collaboration: C-reactive protein concentration and risk of coronary heart disease, stroke, and mortality: An individual participant meta-analysis. Lancet 375: 132-140, 2010.

19. Jousilahti P, Vartiainen E, Tuomilehto J and Puska P: Sex, age, cardiovascular risk factors, and coronary heart disease: A prospective follow-up study of 14786 middle-aged men and women in Finland. Circulation 99: 1165-1172, 1999.

20. Ross R: The pathogenesis of atherosclerosis: A perspective for the 1990s. Nature 362: 801-809, 1993

21. Frostegård J: Immunity, atherosclerosis and cardiovascular disease. BMC Med 11: 117, 2013.

22. Ridker PM, Cushman M, Stampfer MJ, Tracy RP and Hennekens $\mathrm{CH}$ : Inflammation, aspirin, and the risk of cardiovascular disease in apparently healthy men. $N$ Engl J Med 336: 973-979, 1997.

23. Koenig W, Sund M, Fröhlich M, Fischer HG, Löwel H, Döring A, Hutchinson WL and Pepys MB: C-Reactive protein, a sensitive marker of inflammation, predicts future risk of coronary heart disease in initially healthy middle-aged men: Results from the MONICA (Monitoring Trends and Determinants in Cardiovascular Disease) Augsburg Cohort Study, 1984 to 1992. Circulation 99: 237-242, 1999. 
24. Danesh J, Whincup P, Walker M, Lennon L, Thomson A, Appleby P, Gallimore JR and Pepys MB: Low grade inflammation and coronary heart disease: Prospective study and updated meta-analyses. BMJ 321: 199-204, 2000.

25. Ridker PM, Hennekens CH, Buring JE and Rifai N: C-reactive protein and other markers of inflammation in the prediction of cardiovascular disease in women. NEngl J Med 342: 836-843, 2000.

26. Ridker PM: C-reactive protein and the prediction of cardiovascular events among those at intermediate risk: Moving an inflammatory hypothesis toward consensus. J Am Coll Cardiol 49: 2129-2138, 2007.

27. Ridker PM, Rifai N, Rose L, Buring JE and Cook NR: Comparison of C-reactive protein and low-density lipoprotein cholesterol levels in the prediction of first cardiovascular events. N Engl J Med 347: 1557-1565, 2002.

28. Shah PK: Circulating markers of inflammation for vascular risk prediction: Are they ready for prime time. Circulation 101: $1758-1759,2000$

29. Lagrand WK, Visser CA, Hermens WT, Niessen HW, Verheugt FW, Wolbink GJ and Hack CE: C-reactive protein as a cardiovascular risk factor: More than an epiphenomenon? Circulation 100: 96-102, 1999.

30. Paul A, Ko KW, Li L, Yechoor V, McCrory MA, Szalai AJ and Chan L: C-reactive protein accelerates the progression of atherosclerosis in apolipoprotein E-deficient mice. Circulation 109: 647-655, 2004

31. Yu Q, Li Y, Wang Y, Zhao S, Yang P, Chen Y, Fan J and Liu E: $\mathrm{C}$-reactive protein levels are associated with the progression of atherosclerotic lesions in rabbits. Histol Histopathol 27: 529-535, 2012.

32. Sun H, Koike T, Ichikawa T, Hatakeyama K, Shiomi M, Zhang B, Kitajima S, Morimoto M, Watanabe T, Asada Y, et al: C-reactive protein in atherosclerotic lesions: Its origin and pathophysiological significance. Am J Pathol 167: 1139-1148, 2005.

33. de Beer FC, Hind CR, Fox KM, Allan RM, Maseri A and Pepys MB: Measurement of serum C-reactive protein concentration in myocardial ischaemia and infarction. Br Heart $\mathrm{J} 47$ : 239-243, 1982

34. Berk BC, Weintraub WS and Alexander RW: Elevation of C-reactive protein in 'active' coronary artery disease. Am J Cardiol 65: 168-172, 1990.

35. Zaragoza C, Gomez-Guerrero C, Martin-Ventura JL, Blanco-Colio L, Lavin B, Mallavia B, Tarin C, Mas S, Ortiz A and Egido J: Animal models of cardiovascular diseases. J Biomed Biotechnol 2011: 497841, 2011.

36. Torzewski M, Waqar AB and Fan J: Animal models of C-reactive protein. Mediators Inflamm 2014: 683598, 2014.

37. Kumar S, Stecher G and Tamura K: MEGA7: Molecular Evolutionary Genetics Analysis Version 7.0 for Bigger Datasets Mol Biol Evol 33: 1870-1874, 2016.

38. Wang CH, Li SH, Weisel RD, Fedak PW, Dumont AS, Szmitko P, Li RK, Mickle DA and Verma S: C-reactive protein upregulates angiotensin type 1 receptors in vascular smooth muscle. Circulation 107: 1783-1790, 2003.

39. Hirschfield GM, Gallimore JR, Kahan MC, Hutchinson WL, Sabin CA, Benson GM, Dhillon AP, Tennent GA and Pepys MB: Transgenic human C-reactive protein is not proatherogenic in apolipoprotein E-deficient mice. Proc Natl Acad Sci USA 102 8309-8314, 2005.

40. Kovacs A, Tornvall P, Nilsson R, Tegnér J, Hamsten A and Björkegren J: Human C-reactive protein slows atherosclerosis development in a mouse model with human-like hypercholesterolemia. Proc Natl Acad Sci USA 104: 13768-13773, 2007.

41. Teupser D, Weber O, Rao TN, Sass K, Thiery J and Fehling HJ: No reduction of atherosclerosis in C-reactive protein (CRP)-deficient mice. J Biol Chem 286: 6272-6279, 2011.

42. Yu Q, Lin Y, Yang P, Wang Y, Zhao S, Yang P, Fan J and Liu E: $\mathrm{C}$-reactive protein is associated with the progression of acute embolic stroke in rabbit model. J Thromb Thrombolysis 33 301-307, 2012

43. Yu Q, Liu Z, Waqar AB, Ning B, Yang X, Shiomi M, Graham MJ, Crooke RM, Liu E, Dong S, et al: Effects of antisense oligonucleotides against $\mathrm{C}$-reactive protein on the development of atherosclerosis in WHHL rabbits. Mediators Inflamm 2014: 979132, 2014.

44. Tennent GA, Hutchinson WL, Kahan MC, Hirschfield GM Gallimore JR, Lewin J, Sabin CA, Dhillon AP and Pepys MB: TransgenichumanCRPisnot pro-atherogenic,pro-atherothrombotic or pro-inflammatory in apoE ${ }^{-/}$mice. Atherosclerosis 196: $248-255$, 2008.
45. Reifenberg K, Lehr HA, Baskal D, Wiese E, Schaefer SC, Black S, Samols D, Torzewski M, Lackner KJ, Husmann M, et al: Role of C-reactive protein in atherogenesis: Can the apolipoprotein $\mathrm{E}$ knockout mouse provide the answer? Arterioscler Thromb Vasc Biol 25: 1641-1646, 2005.

46. Torzewski M, Reifenberg K, Cheng F, Wiese E, Küpper I, Crain J, Lackner KJ and Bhakdi S: No effect of C-reactive protein on early atherosclerosis in $\mathrm{LDLR}^{-/} /$human $\mathrm{C}$-reactive protein transgenic mice. Thromb Haemost 99: 196-201, 2008.

47. Trion A, de Maat MP, Jukema JW, van der Laarse A, Maas MC, Offerman EH, Havekes LM, Szalai AJ, Princen HM and Emeis JJ: No effect of C-reactive protein on early atherosclerosis development in apolipoprotein $\mathrm{E}^{*} 3$-leiden/human C-reactive protein transgenic mice. Arterioscler Thromb Vasc Biol 25: 1635-1640, 2005.

48. Koike T, Kitajima S, Yu Y, Nishijima K, Zhang J, Ozaki Y, Morimoto M, Watanabe T, Bhakdi S, Asada Y, et al: Human C-reactive protein does not promote atherosclerosis in transgenic rabbits. Circulation 120: 2088-2094, 2009.

49. Pepys MB, Baltz M, Gomer K, Davies AJ and Doenhoff M: Serum amyloid P-component is an acute-phase reactant in the mouse. Nature 278: 259-261, 1979.

50. Fan J, Kitajima S, Watanabe T, Xu J, Zhang J, Liu E and Chen YE: Rabbit models for the study of human atherosclerosis: From pathophysiological mechanisms to translational medicine. Pharmacol Ther 146: 104-119, 2015.

51. Kushner I and Feldmann G: Control of the acute phase response. Demonstration of C-reactive protein synthesis and secretion by hepatocytes during acute inflammation in the rabbit. J Exp Med 148: 466-477, 1978.

52. Ridker PM, Rifai N, Pfeffer MA, Sacks F and Braunwald E; The Cholesterol and Recurrent Events (CARE) Investigators: Long-term effects of pravastatin on plasma concentration of C-reactive protein. Circulation 100: 230-235, 1999.

53. Hutchinson WL, Koenig W, Fröhlich M, Sund M, Lowe GD and Pepys MB: Immunoradiometric assay of circulating C-reactive protein: Age-related values in the adult general population. Clin Chem 46: 934-938, 2000

54. Danesh J, Wheeler JG, Hirschfield GM, Eda S, Eiriksdottir G, Rumley A, Lowe GD, Pepys MB and Gudnason V: C-reactive protein and other circulating markers of inflammation in the prediction of coronary heart disease. N Engl J Med 350: 1387-1397, 2004

55. Haverkate F, Thompson SG, Pyke SD, Gallimore JR and Pepys MB; European Concerted Action on Thrombosis and Disabilities Angina Pectoris Study Group: Production of C-reactive protein and risk of coronary events in stable and unstable angina. Lancet 349: 462-466, 1997.

56. Biasucci LM, Liuzzo G, Grillo RL, Caligiuri G, Rebuzzi AG, Buffon A, Summaria F, Ginnetti F, Fadda G and Maseri A: Elevated levels of $\mathrm{C}$-reactive protein at discharge in patients with unstable angina predict recurrent instability. Circulation 99: 855-860, 1999.

57. Ridker PM: C-reactive protein and risks of future myocardial infarction and thrombotic stroke. Eur Heart J 19: 1-3, 1998.

58. Liuzzo G, Biasucci LM, Gallimore JR, Grillo RL, Rebuzzi AG, Pepys MB and Maseri A: The prognostic value of C-reactive protein and serum amyloid a protein in severe unstable angina. N Engl J Med 331: 417-424, 1994.

59. Ridker PM, Cannon CP, Morrow D, Rifai N, Rose LM, McCabe $\mathrm{CH}$, Pfeffer MA and Braunwald E; Pravastatin or Atorvastatin Evaluation and Infection Therapy-Thrombolysis in Myocardial Infarction 22 (PROVE IT-TIMI 22) Investigators: $\mathrm{C}$-reactive protein levels and outcomes after statin therapy. N Engl J Med 352: 20-28, 2005.

60. Ridker PM, Danielson E, Fonseca FA, Genest J, Gotto AM Jr, Kastelein JJ, Koenig W, Libby P, Lorenzatti AJ, MacFadyen JG, et al; JUPITER Study Group: Rosuvastatin to prevent vascular events in men and women with elevated C-reactive protein. N Engl J Med 359: 2195-2207, 2008

61. RidkerPM,Rifai N,Pfeffer MA, Sacks FM, Moye LA, Goldman S, Flaker GC and Braunwald E; Cholesterol and Recurrent Events (CARE) Investigators: Inflammation, pravastatin, and the risk of coronary events after myocardial infarction in patients with average cholesterol levels. Circulation 98: 839-844, 1998.

62. Ridker PM, Rifai N, Clearfield M, Downs JR, Weis SE, Miles JS and Gotto AM Jr; Air Force/Texas Coronary Atherosclerosis Prevention Study Investigators: Measurement of C-reactive protein for the targeting of statin therapy in the primary prevention of acute coronary events. N Engl J Med 344: 1959-1965, 2001. 
63. Nissen SE, Tuzcu EM, Schoenhagen P, Crowe T, Sasiela WJ, Tsai J, Orazem J, Magorien RD, O'Shaughnessy C and Ganz P; Reversal of Atherosclerosis with Aggressive Lipid Lowering (REVERSAL) Investigators: Statin therapy, LDL cholesterol, C-reactive protein, and coronary artery disease. N Engl J Med 352: 29-38, 2005.

64. Bohula EA, Giugliano RP, Cannon CP, Zhou J, Murphy SA, White JA, Tershakovec AM, Blazing MA and Braunwald E: Achievement of dual low-density lipoprotein cholesterol and high-sensitivity C-reactive protein targets more frequent with the addition of ezetimibe to simvastatin and associated with better outcomes in IMPROVE-IT. Circulation 132: 1224-1233, 2015

65. Ridker PM, Everett BM, Thuren T, MacFadyen JG, Chang WH Ballantyne C, Fonseca F, Nicolau J, Koenig W, Anker SD, et al: CANTOS Trial Group: Antiinflammatory therapy with Canakinumab for atherosclerotic disease. N Engl J Med 377: 1119-1131, 2017.

66. Jialal I, Devaraj S and Venugopal SK: C-reactive protein: Risk marker or mediator in atherothrombosis? Hypertension 44: 6-11, 2004.

67. Labarrere CA and Zaloga GP: C-reactive protein: From innocent bystander to pivotal mediator of atherosclerosis. Am J Med 117: 499-507, 2004

68. Verma S, Devaraj S and Jialal I: Is C-reactive protein an innocent bystander or proatherogenic culprit? C-reactive protein promotes atherothrombosis. Circulation 113: 2135-2150, discussion 2150 2006.

69. Pasceri V, Cheng JS, Willerson JT and Yeh ET: Modulation of C-reactive protein-mediated monocyte chemoattractant protein-1 induction in human endothelial cells by anti-atherosclerosis drugs. Circulation 103: 2531-2534, 2001.

70. Boring L, Gosling J, Cleary M and Charo IF: Decreased lesion formation in $\mathrm{CCR} 2^{-1-}$ mice reveals a role for chemokines in the initiation of atherosclerosis. Nature 394: 894-897, 1998.

71. Gu L, Okada Y, Clinton SK, Gerard C, Sukhova GK, Libby P and Rollins BJ: Absence of monocyte chemoattractant protein-1 reduces atherosclerosis in low density lipoprotein receptor-deficient mice. Mol Cell 2: 275-281, 1998.

72. Pasceri V, Willerson JT and Yeh ET: Direct proinflammatory effect of C-reactive protein on human endothelial cells Circulation 102: 2165-2168, 2000.

73. Qamirani E, Ren Y, Kuo L and Hein TW: C-reactive protein inhibits endothelium-dependent NO-mediated dilation in coronary arterioles by activating p38 kinase and $\mathrm{NAD}(\mathrm{P}) \mathrm{H}$ oxidase. Arterioscler Thromb Vasc Biol 25: 995-1001, 2005.

74. Devaraj S, Yun JM, Adamson G, Galvez J and Jialal I: C-reactive protein impairs the endothelial glycocalyx resulting in endothelial dysfunction. Cardiovasc Res 84: 479-484, 2009.

75. Hein TW, Singh U, Vasquez-Vivar J, Devaraj S, Kuo L and Jialal I: Human C-reactive protein induces endothelial dysfunction and uncoupling of eNOS in vivo. Atherosclerosis 206: 61-68, 2009.

76. Devaraj S, Kumaresan PR and Jialal I: C-reactive protein induces release of both endothelial microparticles and circulating endothelial cells in vitro and in vivo: Further evidence of endothelial dysfunction. Clin Chem 57: 1757-1761, 2011.

77. Venugopal SK, Devaraj S, Yuhanna I, Shaul P and Jialal I: Demonstration that C-reactive protein decreases eNOS expression and bioactivity in human aortic endothelial cells Circulation 106: 1439-1441, 2002.

78. Verma S, Kuliszewski MA, Li SH, Szmitko PE, Zucco L, Wang CH,Badiwala MV, Mickle DA, Weisel RD, Fedak PW, et al: C-reactive protein attenuates endothelial progenitor cell survival, differentiation, and function: Further evidence of a mechanistic link between $\mathrm{C}$-reactive protein and cardiovascular disease. Circulation 109: 2058-2067, 2004

79. Verma S, Li SH, Badiwala MV, Weisel RD, Fedak PW, Li RK, Dhillon B and Mickle DA: Endothelin antagonism and interleukin-6 inhibition attenuate the proatherogenic effects of C-reactive protein. Circulation 105: 1890-1896, 2002.

80. Verma S, Wang CH, Li SH, Dumont AS, Fedak PW, Badiwala MV, Dhillon B, Weisel RD, Li RK, Mickle DA, et al: A self-fulfilling prophecy: C-reactive protein attenuates nitric oxide production and inhibits angiogenesis. Circulation 106: 913-919, 2002.

81. Teoh H, Quan A, Lovren F, Wang G, Tirgari S, Szmitko PE, Szalai AJ, Ward ME and Verma S: Impaired endothelial function in C-reactive protein overexpressing mice. Atherosclerosis 201: 318-325, 2008

82. Fichtlscherer S, Rosenberger G, Walter DH, Breuer S, Dimmeler S and Zeiher AM: Elevated C-reactive protein levels and impaired endothelial vasoreactivity in patients with coronary artery disease. Circulation 102: 1000-1006, 2000
83. Tomai F, Crea F, Gaspardone A, Versaci F, Ghini AS, Chiariello L and Gioffrè PA: Unstable angina and elevated c-reactive protein levels predict enhanced vasoreactivity of the culprit lesion. Circulation 104: 1471-1476, 2001.

84. Cleland SJ, Sattar N, Petrie JR, Forouhi NG, Elliott HL and Connell JM: Endothelial dysfunction as a possible link between C-reactive protein levels and cardiovascular disease. Clin Sci (Lond) 98: 531-535, 2000.

85. Devaraj S, Kumaresan PR and Jialal I: Effect of C-reactive protein on chemokine expression in human aortic endothelial cells. J Mol Cell Cardiol 36: 405-410, 2004.

86. Tabas I, García-Cardeña G and Owens GK: Recent insights into the cellular biology of atherosclerosis. J Cell Biol 209: 13-22, 2015.

87. Calabró P, Willerson JT and Yeh ET: Inflammatory cytokines stimulated C-reactive protein production by human coronary artery smooth muscle cells. Circulation 108: 1930-1932, 2003.

88. Chistiakov DA, Orekhov AN and Bobryshev YV: Vascular smooth muscle cell in atherosclerosis. Acta Physiol (Oxf) 214: 33-50, 2015

89. Ryu J, Lee CW, Shin JA, Park CS, Kim JJ, Park SJ and Han KH: FcgammaRIIa mediates C-reactive protein-induced inflammatory responses of human vascular smooth muscle cells by activating NADPH oxidase 4. Cardiovasc Res 75: 555-565, 2007.

90. Liu N, Liu J, Ji Y, Lu P, Wang C and Guo F: C-reactive protein induces TNF- $\alpha$ secretion by $\mathrm{p} 38$ MAPK-TLR4 signal pathway in rat vascular smooth muscle cells. Inflammation 34: 283-290, 2011.

91. Liu N, Liu JT, Ji YY and Lu PP: C-reactive protein triggers inflammatory responses partly via TLR4/IRF3/NF- $\mathrm{B}$ signaling pathway in rat vascular smooth muscle cells. Life Sci 87: 367-374, 2010

92. Cermak J, Key NS, Bach RR, Balla J, Jacob HS and Vercellotti GM: C-reactive protein induces human peripheral blood monocytes to synthesize tissue factor. Blood 82: 513-520, 1993.

93. Nakagomi A, Freedman SB and Geczy CL: Interferon-gamma and lipopolysaccharide potentiate monocyte tissue factor induction by C-reactive protein: Relationship with age, sex, and hormone replacement treatment. Circulation 101: 1785-1791, 2000.

94. Williams TN,Zhang CX, Game BA, HeL and Huang Y: C-reactive protein stimulates MMP-1 expression in U937 histiocytes through $\mathrm{Fc}$ [gamma]RII and extracellular signal-regulated kinase pathway: An implication of CRP involvement in plaque destabilization. Arterioscler Thromb Vasc Biol 24: 61-66, 2004.

95. Ballou SP and Lozanski G: Induction of inflammatory cytokine release from cultured human monocytes by C-reactive protein. Cytokine 4: 361-368, 1992.

96. Torzewski M, Rist C, Mortensen RF, Zwaka TP, Bienek M, Waltenberger J, Koenig W, Schmitz G, Hombach V and Torzewski J: C-reactive protein in the arterial intima: Role of C-reactive protein receptor-dependent monocyte recruitment in atherogenesis. Arterioscler Thromb Vasc Biol 20: 2094-2099, 2000

97. Reynolds GD and Vance RP: C-reactive protein immunohistochemical localization in normal and atherosclerotic human aortas. Arch Pathol Lab Med 111: 265-269, 1987.

98. Yasojima K, Schwab C, McGeer EG and McGeer PL: Generation of C-reactive protein and complement components in atherosclerotic plaques. Am J Pathol 158: 1039-1051, 2001.

99. Kobayashi S, Inoue N, Ohashi Y, Terashima M, Matsui K, Mori T, Fujita H, Awano K, Kobayashi K, Azumi H, et al: Interaction of oxidative stress and inflammatory response in coronary plaque instability: Important role of C-reactive protein. Arterioscler Thromb Vasc Biol 23: 1398-1404, 2003.

100. Seifert PS and Kazatchkine MD: The complement system in atherosclerosis. Atherosclerosis 73: 91-104, 1988.

101. Torzewski J, Bowyer DE, Waltenberger J and Fitzsimmons C Processes in atherogenesis: Complement activation. Atherosclerosis 132: 131-138, 1997

102. Niculescu F, Rus HG and Vlaicu R: Immunohistochemical localization of C5b-9, S-protein, C3d and apolipoprotein B in human arterial tissues with atherosclerosis. Atherosclerosis 65 : $1-11,1987$

103. Torzewski J, Torzewski M, Bowyer DE, Fröhlich M, Koenig W, Waltenberger J, Fitzsimmons C and Hombach V: C-reactive protein frequently colocalizes with the terminal complement complex in the intima of early atherosclerotic lesions of human coronary arteries. Arterioscler Thromb Vasc Biol 18: 1386-1392, 1998. 
104. Yousuf O, Mohanty BD, Martin SS, Joshi PH, Blaha MJ, Nasir K, Blumenthal RS and Budoff MJ: High-sensitivity C-reactive protein and cardiovascular disease: A resolute belief or an elusive link? J Am Coll Cardiol 62: 397-408, 2013.

105. Bielas H, Meister-Langraf RE, Schmid JP, Barth J, Znoj H, Schnyder U, Princip M and von Känel R: C-reactive protein as a predictor of posttraumatic stress induced by acute myocardial infarction. Gen Hosp Psychiatry 53: 125-130, 2018.

106. Best LG, Zhang Y, Lee ET, Yeh JL, Cowan L, Palmieri V, Roman M, Devereux RB, Fabsitz RR, Tracy RP, et al: C-reactive protein as a predictor of cardiovascular risk in a population with a high prevalence of diabetes: The Strong Heart Study. Circulation 112: 1289-1295, 2005.

107. Hurlimann J, Thorbecke GJ and Hochwald GM: The liver as the site of C-reactive protein formation. J Exp Med 123: 365-378, 1966.

108. Eklund CM: Proinflammatory cytokines in CRP baseline regulation. Adv Clin Chem 48: 111-136, 2009.

109. Jensen HS: C-reactive protein. Ugeskr Laeger 162: 2453-2456, 2000 (In Danish).

110.Deban L, Bottazzi B, Garlanda C, de la Torre YM and Mantovani A: Pentraxins: Multifunctional proteins at the interface of innate immunity and inflammation. Biofactors 35 138-145, 2009.
111. Laskowitz DT, Lee DM, Schmechel D and Staats HF: Altered immune responses in apolipoprotein E-deficient mice. J Lipid Res 41: 613-620, 2000.

112. Grainger DJ, Reckless J and McKilligin E: Apolipoprotein E modulates clearance of apoptotic bodies in vitro and in vivo, resulting in a systemic proinflammatory state in apolipoprotein E-deficient mice. J Immunol 173: 6366-6375, 2004

113. Li HY, Liu XL, Liu YT, Jia ZK, Filep JG, Potempa LA, Ji SR and $\mathrm{Wu}$ Y: Matrix sieving-enforced retrograde transcytosis regulates tissue accumulation of $\mathrm{C}$-reactive protein. Cardiovasc Res 115: 440-452, 2019.

114. Su HX, Zhou HH, Wang MY, Cheng J, Zhang SC, Hui F, Chen XZ, Liu SH, Liu QJ, Zhu ZJ, et al: Mutations of C-reactive protein (CRP) -286 SNP, APC and p53 in colorectal cancer: Implication for a CRP-Wnt crosstalk. PLoS One 9: e102418, 2014.

This work is licensed under a Creative Commons Attribution-NonCommercial-NoDerivatives 4.0 International (CC BY-NC-ND 4.0) License. 